\title{
Structure of heavy and light chains of blood coagulation factor VIII (FVIII) involved in the activation of FVIII
}

\author{
Sang Hwan Oh, ${ }^{1,2}$ Hye Weon $\mathrm{Kim}^{1}$ and \\ You Jin Kim ${ }^{1}$ \\ 1 Department of Biochemistry and Molecular Biology, \\ College of Medicine, Yonsei University, 134 Shin Chon Dong, \\ Suh Dae Moon Ku, Seoul 120-752, Korea \\ 2 Corresponding author \\ Accepted 9 May 1997
}

Abbreviations: FVIII, factor FVIII; FVIII-H, FVIII-heavy chain; FXa, activated factor X; FVIII RAg, FVIII related antigen; FVIII-L, FVIII light chain

\section{Inroduction}

Coagulation factor VIII (FVIII) participates in the activation of factor $\mathrm{X}(\mathrm{FX})$ by factor IX as a cofactor in the blood coagulation cascade, and its activation is accomplished by limited proteolysis of both heavy and light chains (Lollar et al., 1985; Mertens et al., 1985; Kaufman, 1992).

Thrombin and FXa are known to be responsible for the activation of FVIII by cleavage of heavy and light chains. Due to the limited proteolysis by thrombin and FXa at the B domain of FVIII, FVIII heavy chain (FVIII-H) is heterogeneous (Andersson et al., 1986). Three major cleaving sites of FVIII by thrombin during activation are $\mathrm{Arg}^{336}, \mathrm{Arg}^{740}$ and $\mathrm{Arg}^{1689}$. FXa also cleaves at the same sites defined by thrombin and additionally, at $\operatorname{Arg}^{336}$ in the heavy chain and at $\operatorname{Arg}^{1721}$ in the light chain (Eaton et al., 1986). The additional cleavage at $\mathrm{Arg}^{336}, \mathrm{Arg}^{1721}$ has been thought to inactivate FVIII with the dissociation of subunits. However, recent observation suggested that cleavage at $\operatorname{Arg}^{1719}$ or $\operatorname{Arg}^{1721}$ in the light chain may be unrelated to FVIII inactivation (Fay, 1993). Therefore inactivation of FVIII by additional cleavage by thrombin or FXa in the light chain remains controversial, and the precise sites of proteolytic cleavage of FVIII in the process of FVIII activation remains unclear.

It is neccessary to define the role of each FVIII subunits in the generation of cofactor activity. In the present study, we attempted to determine the structural requirement of proteolytic subunits for the assembly and regeneration of FVIII activity.

\section{Materials and Methods}

\section{Preparation of immunoaffinity column}

Polyclonal anti-human FVIII related antigen (FVIIIRAg) antibody (Sigma, St. Louis, U.S.A.) dissolved in a coupling buffer $\left(0.1 \mathrm{M} \mathrm{NaHCO}_{3}, \mathrm{pH} 8.3\right.$ containing $\left.0.5 \mathrm{M} \mathrm{NaCl}\right)$ at a concentration of $20 \mathrm{mg} / \mathrm{ml}$ was added to $\mathrm{CNBr}$-activated Sepharose-4B gel (Pharmacia, Sweden) swelled in 1 $\mathrm{mM} \mathrm{HCl}$ and mixed overnight at $4^{\circ} \mathrm{C}$ with gentle stirring. Uncoupled excess ligands were washed out with $5 \mathrm{gel}$ volumes of coupling buffer and the remaining active groups on the gel were blocked with $0.1 \mathrm{M}$ Tris-HCl buffer, $\mathrm{pH}$ 8.0, for two hours. The product was washed with at least three cycles of alternating $\mathrm{pH}$ buffers. Each cycle consists of a wash with $0.1 \mathrm{M}$ acetate buffer, $\mathrm{pH} 4.0$ containing $0.5 \mathrm{M} \mathrm{NaCl}$ followed by a wash with $0.1 \mathrm{M}$ Tris- $\mathrm{HCl}$ buffer, $\mathrm{pH} 8.0$ containing $0.5 \mathrm{M} \mathrm{NaCl}$. The gel was equilibrated in FVIII buffer ( $20 \mathrm{mM}$ imidazole/ 0.15 $\mathrm{M} \mathrm{NaCl} / 0.1 \mathrm{M}$ L-lysine/0.02\% $\mathrm{NaN}_{3}, \mathrm{pH} 6.8$ ) and packed into an immunoadsorbent column $(2 \times 12 \mathrm{~cm})$. 


\section{Purification of FVIII and FVIII subunits}

A commercial FVIII concentrate (HemophilM, Baxter, U.S.A.) containing about 10,000 units was reconstituted with $200 \mathrm{ml}$ of FVIII buffer and was applied to the immunoadsorbent column equilibrated with the FVIII buffer. The column was washed with one liter of FVIII buffer containing $0.5 \mathrm{M} \mathrm{NaCl}$, and FVIII was then eluted from FVIIIRAg bound gel with FVIII buffer containing $0.35 \mathrm{M}$ $\mathrm{CaCl}_{2}$. Fractions containing FVIII activity were pooled and concentrated 100 -folds by dialysis through dialysis membrane against the powder form of polyethylene glycol (MW 400,000). The concentrate was then subjected to an extensive dialysis against a buffer containing $0.15 \mathrm{M}$ $\mathrm{NaCl}, 25 \mathrm{mM}$ EDTA, $10 \mathrm{mM}$ benzamidine and $20 \mathrm{mM}$ Tris ( $\mathrm{pH} 7.4$ ) in order to dissociate FVIII into its subunits. The EDTA-dissociated FVIII-H was isolated by immunoaffinity chromatography using a polyclonal antibody against FVIII-H peptide fragment produced in E. coli (Kim and Oh, 1994). FVIII light chain (FVIII-L) was isolated from the FVIII-H removed fraction by immunoaffinity chromatography using a monoclonal antibody against FVIII-L. Thrombin or FXa-cleaved FVIII-L derivatives were prepared from FVIII-L treated with thrombin (2 units $/ 10 \mu \mathrm{g})$ or FXa (2 units $/ 10 \mu \mathrm{g})$ for one hour at $37^{\circ} \mathrm{C}$ in the presence of a buffer consisting of $100 \mathrm{mM} \mathrm{NaCl}$, $10 \mathrm{mM} \mathrm{CaCl}_{2}$, and $50 \mathrm{mM}$ Tris, $\mathrm{pH} 7.4$ followed by gel filtration (Sephacryl S 300 column, $1.2 \times 65 \mathrm{~cm}$ ). Thrombin cleaved FVIII-H derivatives were prepared as $A_{1}$ and $A_{2}$ complex after immunoaffinity chromatography.

\section{FVIII heterodimer formation assay}

FVIII heterodimer formation was assayed by ELISA using FVIII-L specific mouse monoclonal antibody as primary antibody and horse raddish peroxidase-conjugated antimouse IgG antibody as secondary antibody. FVIII-H (200 pmol) dissolved in a coating buffer (50 $\mathrm{mM} \mathrm{NaHCO}_{3}$, $0.02 \% \mathrm{NaN}_{3}, \mathrm{pH}$ 9.6) were immmobilized to microtiter plates $\left(100 \mu \mathrm{l} /\right.$ well) overnight at $4^{\circ} \mathrm{C}$. Wells were washed with $10 \mathrm{mM}$ Tris- $\mathrm{HCl}, 150 \mathrm{mM} \mathrm{NaCl}, 0.1 \%$ Tween $20, \mathrm{pH}$ 7.4 (TBST) and blocked for $2 \mathrm{~h}$ at room temperature with same buffer containing $10 \%(\mathrm{w} / \mathrm{v})$ non-fat dry milk. Various amount of FVIII-L derivatives dissolved in 100 $\mu \mathrm{l}$ of phosphate buffered saline $(\mathrm{pH} \mathrm{7.4)}$ were added to each wells and incubated for $16 \mathrm{~h}$ at $4^{\circ} \mathrm{C}$. After washing the wells with TBST 3 times, the peroxidase-conjugated secondary antibody was added (2,000-fold dilution in blocking solution) and incubated another two hours. After incubation, wells were washed 4 times with TBST and $100 \mu$ l of peroxidase substrate solution, prepared by dissolving (10 mg o-phenylenediamine dihydrochloride and $10 \mu \mathrm{l}$ of $\mathrm{H}_{2} \mathrm{O}_{2}$ in $25 \mathrm{ml}$ of reaction buffer $(20 \mathrm{mM}$ citrate, $20 \mathrm{mM}$ sodium phosphate, $\mathrm{pH}$ 5.6) was added to develop the color. After color development, $100 \mu \mathrm{l}$ of 1.25 $\mathrm{M} \mathrm{H}_{2} \mathrm{SO}_{4}$ was added and absorbance at $490 \mathrm{~nm}$ was measured. Standard plasma-derived FVIII (1 units $/ \mathrm{ml}$ ) served as a reference.

\section{FVIII subunits association assay}

FVIII subunit association assay was performed with a fixed concentration of FVIII-H subunit and varied in the amount of FVIII-L concentration and incubation time. The incubation buffer (FVIII buffer) contained $40 \mathrm{mM} \mathrm{CaCl}_{2}$ and $400 \mathrm{mM} \mathrm{NaCl}$ in the assay. Association of FVIII subunits was monitored by measuring FVIII activity and association constant was determined from the equation; FVIII-H + FVIII-L $\stackrel{\text { k1 }}{\leftrightarrow}$ FVIII. V=k 1 [FVIII-H][FVIII-L] and in integrated expression, $\mathrm{k}_{1} \mathrm{t}=1 / \mathrm{a}_{0}-\mathrm{b}_{0} \ln \mathrm{b}_{0}\left(\mathrm{a}_{0}-\mathrm{p}\right) /$ $a_{0}\left(b_{0}-p\right) . k_{1}$ represents the association rate constant and $p$ is the concentration of FVIII dimer formed at time t. $a_{0}$ is the initial concentration of $\mathrm{FVIII-H}$ and $b_{0}$ is the initial concentration of FVIII-L.

\section{Measurement of FVIII activity and protein content}

Cofactor activity of FVIII was assayed by Coamatic factor FVIII kit (Chromogenix AB, Stockholm, Sweden). The principle of the method is the measurement of the FVIIIdependent generation of FXa from FX in the presence of factor IXa (Carlebjork et al., 1987). Total protein content was determined by Bradford method (Bradford, 1976) and the amount of FVIII and its subunit derivatives were quantified by ELISA using anti-FVIII-H and anti-FVIII-L antibodies according to the method of Johnston and Thorpe (1987). A purified FVIII preparation with known concentration was used as the reference.

\section{Western blot analysis of FVIII}

Western blot analysis of FVIII and its subunit derivatives was performed according to the method described by Burnette (1981). SDS-PAGE was performed according to the method of Laemmli (1970). FVIII subunits in the gel were electrotransferred to nitrocellulose membrane and immunodetection was performed using a polyclonal anti-FVIII-H rabbit antiserum or monoclonal anti-FVIII-L mouse antibody as primary antibodies and peroxidaseconjugated anti-rabbit or anti-mouse IgG antibodies as secondary antibodies (Sigma). Immunodetection of FVIII and its subunits was performed by ECL Western blotting protocol (Amersham, Buckinghamshire, U.K.).

\section{Results}

\section{Purification of FVIII}

A 2,413-fold purification of FVIII from a commercial FVIII concentrate was achieved by immunoaffinity column chromatography (Table 1). Specific activity of the purified FVIII was 2,485 units/mg and thrombin treatment increased FVIII activity about 2 folds. The peak fraction eluted from the immunoaffinity column contained about half of total FVIII activity and the presence of two subunits (FVIII-H and FVIII-L) were identified by Western blot immunodetection analysis in the present study (Figure 1). 
Table 1. Purification of FVIII from FVIII concentrate

\begin{tabular}{lcccc}
\hline Step & $\begin{array}{c}\text { Total protein } \\
(\mathrm{mg})\end{array}$ & $\begin{array}{c}\text { Total activity } \\
\text { (unit) }\end{array}$ & $\begin{array}{c}\text { Specific activity } \\
\text { (unit/mg) }\end{array}$ & $\begin{array}{c}\text { Fold } \\
\text { purification }\end{array}$ \\
\hline $\begin{array}{l}\text { Commercial } \\
\text { FVIII concentrate }\end{array}$ & 4,500 & 3,408 & 0.76 & - \\
$\begin{array}{l}\text { Affinity column } \\
\text { (pooled) }\end{array}$ & 1.10 & 2,010 & $1,827.30$ & 2,403 \\
$\begin{array}{l}\text { Affinity column } \\
\text { (peak fraction) }\end{array}$ & 0.45 & 1,121 & $2,485.00$ & 3,270 \\
\hline
\end{tabular}

*: FVIII activity was assayed by coamatic factor VIII assay kit and unit of activity represents the amount of cofactor activity of FVIII in $1 \mathrm{ml}$ of standard reference plasma (Sigma Chem. Co., St. Louis, USA).

Treatment of EDTA (25 mM) dissociated FVIII into its subunits, FVIII-H and FVIII-L and thrombin treatment to a major FVIII-H (96 kDa) resulted in 2 peptides of 50 $\mathrm{kDa}$ and $40 \mathrm{kDa}$. Treatment of FVIII-L with thrombin and FXa resulted in the appearance of FVIII-L dervatives of $72 \mathrm{kDa}$ and $65 \mathrm{kDa}$, respectively (Figure 2).

\section{Restoration of FVIII activity}

Recombination of FVIII-H with FVIII-L ${ }^{72}$ restored FVIII activity and the activity was slightly decreased when FVIII-L ${ }^{65}$ was reassembled with FVIII-H (Table 2). Heavy chain treated with thrombin was cleaved into two peptides

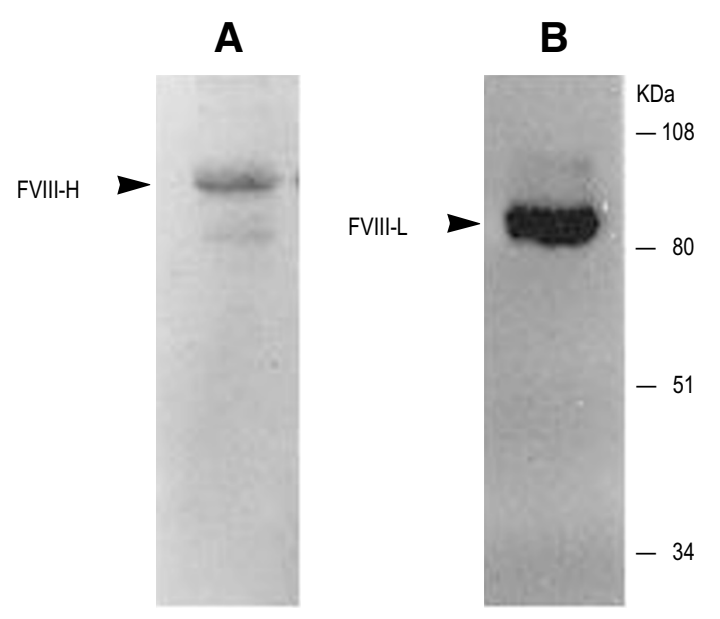

Figure 1. Western blot immunodetection of FVIII protein purified from FVIII concentrate. Protein $(10 \mu \mathrm{g})$ was subjected to SDS-PAGE and electrotransfered to nitrocellulose membrane. (A) Polyclonal anti-FVIII-H antibody was used as a primary antibody. (B) Monoclonal anti-FVIII-L antibody was used as a primary antibody. Horse raddish peroxidase-conjugated anti-lgG antibodies corresponding to each primary antibodies were used as secondary antibodies. of $50 \mathrm{kDa}\left(\mathrm{A}_{1}\right)$ and $40 \mathrm{kDa}\left(\mathrm{A}_{2}\right)$ as shown in Figure 3, and reassociation of $A_{1}, A_{2}$ and FVIII-L ${ }^{72}$ in the presence of $\mathrm{CaCl}_{2}(10 \mathrm{mM})$ and $\mathrm{NaCl}(100 \mathrm{mM})$ bought about cofactor activity suggesting the formation of a heterotrimer. Treatment of EDTA $(10 \mathrm{mM})$ to the heterotrimers formed from $A_{1}, A_{2}$ and FVIII-L ${ }^{72}$ or FVIII-L ${ }^{65}$ abolished FVIII activity indicating that the formation of heterotrimer is calcium-dependent.

\section{Association of FVIII subunits}

Reassociation of heavy chain with either of light chain derivatives brought about the formation of heterodimers which have high cofactor activity. The association of FVIII$\mathrm{H}$ and FVIII-L needed $\mathrm{CaCl}_{2}(40 \mathrm{mM})$, and the addition of 2-mercaptoethanol $(1.0 \mathrm{mM})$ increased the rate of association. The association constant of heavy and light chain was $39 \pm 7 \mathrm{M}^{-1} \mathrm{sec}^{-1}$, and the association constant $\left(28 \pm 6 \mathrm{M}^{-1} \mathrm{sec}^{-1}\right)$ of heavy chain with thrombin-cleaved light chain (FVIII-L ${ }^{72}$ ) was 2 folds faster (Table 3, Figure 4) compared to that $\left(12 \pm 3 \mathrm{M}^{-1} \mathrm{sec}^{-1}\right)$ of heavy chain with FXa-cleaved light chain (FVIII-L $\left.{ }^{65}\right)$.

Table 2. Generation of FVIII activity from calcium-dependent reassociation of FVIII subunits and derivatives. FVIII subunits or derivatives were combined and incubated for $16 \mathrm{~h}$ at $20^{\circ} \mathrm{C}$ in a buffer containing $400 \mathrm{mM} \mathrm{NaCl}, 1 \%$ human serum albumin, $20 \mathrm{mM}$ Hepes ( $\mathrm{pH} 7.2)$ with or without $\mathrm{CaCl}_{2}(40 \mathrm{mM})$. All values are mean of duplicate determinations.

\begin{tabular}{|c|c|c|}
\hline $\begin{array}{l}\text { FVIII subunits } \\
\text { and derivatives }\end{array}$ & $\begin{array}{c}\mathrm{Ca}^{2+} \\
(40 \mathrm{mM})\end{array}$ & $\begin{array}{l}\text { FVIII cofactor } \\
\text { activity (unit } / \mathrm{ml} \text { ) }\end{array}$ \\
\hline FVIII-H + FVIII-L & + & 3.4 \\
\hline FVIII-H + FVIII-L & - & 0.4 \\
\hline FVIII-H + FVIII-L 72 & + & 4.1 \\
\hline FVIII-H + FVIII-L 65 & + & 3.7 \\
\hline $\begin{array}{l}\text { FVIII-H }{ }^{50}+F V I I I-H^{40} \\
+ \text { FVIII-L } 72\end{array}$ & + & 3.3 \\
\hline $\begin{array}{l}\text { FVIII-H50 + FVIII-H } 40 \\
+ \text { FVIII-L }{ }^{72}\end{array}$ & - & $<0.1$ \\
\hline
\end{tabular}


Table 3. Association rate constant $\left(k_{\text {assoc }}\right)$ of FVIII-L derivatives for FVIII-H. Values were obtained from the first order kinetics of association velocity plotted in Figure 4. and from equation, FVIII-H + FVIII-L $\leftrightarrow F V I I I, v=k_{a s s o c}[F V I I I-H][F V I I I-L]$ or $k_{a s s o c} t=1 / a_{0}-b_{0}$ In $b_{0}\left(a_{0}-p\right) / a_{0}\left(b_{0}-p\right)$, where $p$ is the concentration of dimer formed at time $t$ and $a_{0}$ is the initial concentration of FVIII-H and $b_{0}$ is the initial concentration of FVIII-L derivative.

\begin{tabular}{lc}
\hline FVIII-L derivatives & $k_{\text {assoc }}\left(\mathrm{M}^{-1} \cdot \mathrm{sec}^{-1}\right)$ \\
\hline FVIII-L (whole) & $39 \pm 7$ \\
FVIII-L72 & $28 \pm 6$ \\
FVIII-L65 & $12 \pm 3$ \\
\hline
\end{tabular}

A 12

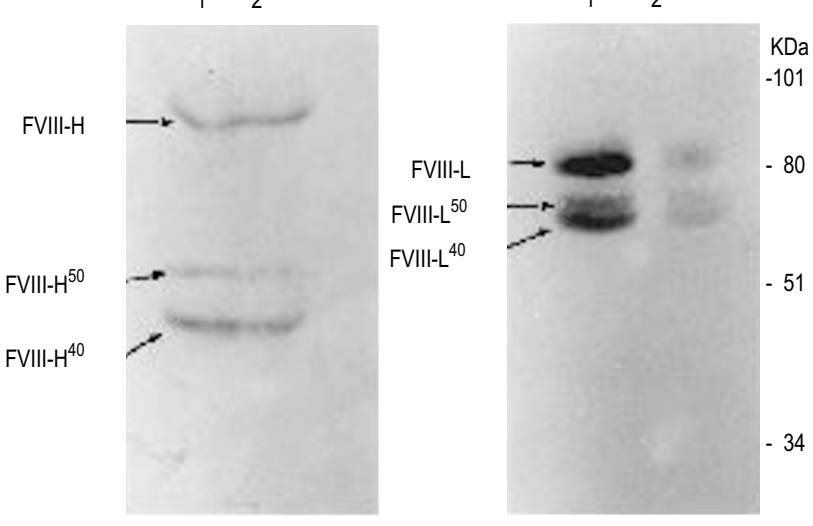

Figure 2. Western blot immunodetection of FVIII-H and FVIII-L proteolyzed with thrombin or FXa. A, FVIII-H $(10 \mu \mathrm{g})$ treated with $\alpha$-thronbin ( 2 units) for $2 \mathrm{~h}$ at $37^{\circ} \mathrm{C}$. B, FVIII-L $(10 \mu \mathrm{g})$ treated with FXa (2 units) for $2 \mathrm{~h}$ at $37^{\circ} \mathrm{C}$. The proteolyzed peptides in duplicate (lane 1 and 2 each) were subjected to SDS polyacrylamide gel electrophoresis and electrotransfered to nitocellulose membrane. FVIII-H or FVIII-L was detected using FVIII-H and FVIII-L specific antibodies as in Figure 1.

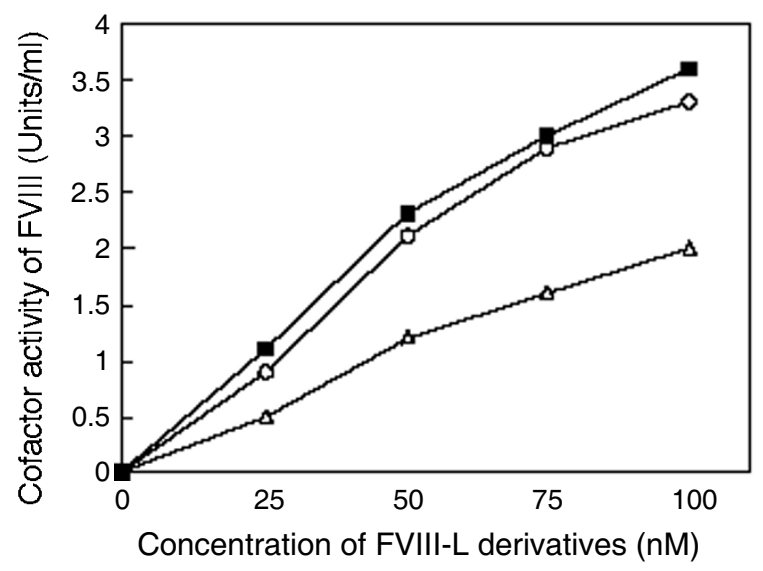

Figure 3. Generation of FVIII activity from complexes of FVIII-H and FVIII-L derivatives Varying concentration of FVIII-L $(\square)$, FVIII-L ${ }^{72}(\bigcirc)$, and FVIII-L ${ }^{65}(\triangle)$ were reassembled with $\mathrm{FVIII-H}(200 \mathrm{nM})$. FVIII subunit and its derivatives were incubated for $1 \mathrm{~h}$ in $400 \mathrm{mM} \mathrm{NaCl}, 40 \mathrm{mM} \mathrm{CaCl}, 1 \%$ human serum albumin, $20 \mathrm{mM}$ Hepes (pH 7.2) and FVIII cofactor activity was assayed according to Coamatic FVIII assay method (Carlebjok et al., 1987).

\section{Discussion}

An extensive purification of FVIII from FVIII concentrate was achieved by immunoaffinity chromatography in the present study, although it was partially pure. The final product had a specific activity of 2,485 units $/ \mathrm{mg}$ protein, but further purification has not been attempted in the present study due to the shortage of the concentrate. The overall recovery of FVIII activity during purification was about $60 \%$ and the activity in the peak fraction was about $30 \%$ with 3,270 folds purification, indicating that immunoaffinity column chromatography was an efficient step to prepare FVIII in a nearly pure form.

The use of an anti-FVIIIRAg (anti-FVIII-related antigen) monoclonal antibody in the preparation of immunoaffinity column had an advantage over anti-FVIIIc antibody since FVIII molecules are tightly bound to von Willebrand factor (vWF) in a mole ratio of 50:1 in human plasma as well as in commercial FVIII concentrate. FVIII molecules are stabilized in plasma in association with von Willebrand factor and they are unlikely to be in free forms (Leyte et al., 1989).

FVIII is synthesized as a single peptide having a sequencial domain of A1-A2-B-A3-C1-C2 (Tool et al., 1984) of which $\mathrm{B}$ domain is known to be unrelated to cofactor activity(Vehar et al., 1984). Initial proteolytic activation of FVIII involves the formation of heterodimer of FVIII-H (A1A2-B) and FVIII-L (A3-C1-C2) after limited proteolysis by thrombin or $\mathrm{FXa}$. A1 is associated noncovalently with A2 and FVIII-L (A3-C1-C2) and is divalent metal ion dependent (Andersson et al., 1986).

It has been reported that the molecular weight of FVIII is ranged between 85 and $285 \mathrm{kDa}$ (Hoyer and Trabold, 1981) and that FVIII-H appears as heterogeneous in

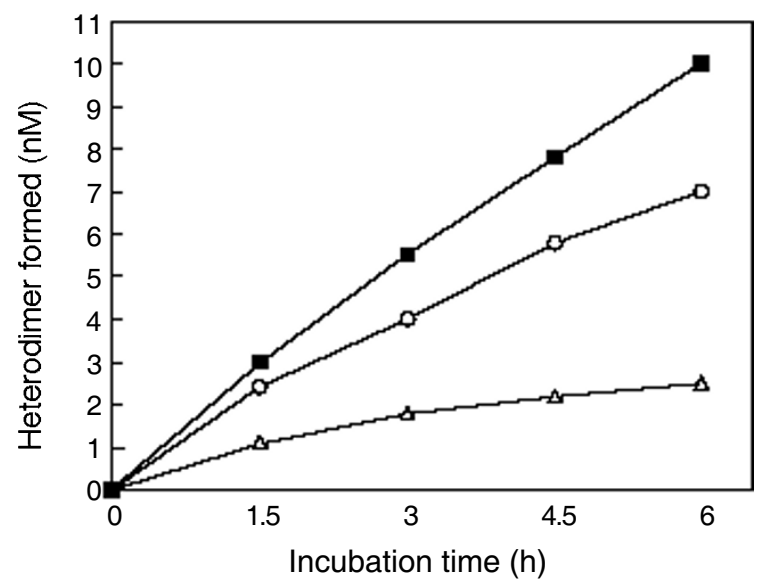

Figure 4. Reassociation of FVIII-H with FVIII-L or its derivatives. FVIII-H (200 nM) was incubated with FVIII-L $(\square)$, FVIII-L ${ }^{72}(\bigcirc)$, or FVIII-L ${ }^{65}(\triangle)$ at $20^{\circ} \mathrm{C}$ and heterodimers formed at various incubation time were estimated by assaying the binding of FVIII-L subunits to FVIII-H. The detailed method is described in the text. 
molecular weights (122 kDa, $96 \mathrm{kDa}$ and $40 \mathrm{kDa}$ ). The purified FVIII in the present study showed FVIII-H as 96 $\mathrm{kDa}$ and FVIII-L as $81 \mathrm{kDa}$ when Western blot immunodetection of the EDTA-dissociated subunits of FVIII was performed. This result is consistent with the values reported by Fulcher and Zimmerman (1982).

Thrombin treatment to a major form of FVIII-H (96 $\mathrm{kDa}$ ) in the present study released two peptides with molecular masses of $50 \mathrm{kDa}$ and $40 \mathrm{kDa}$ indicating the selective cleavage of FVIII-H at $\mathrm{Arg}^{336}$ by thrombin. Thrombin treatment to FVIII-L $(81 \mathrm{kDa})$ released a peptide with molecular weight of $72 \mathrm{kDa}$, a little smaller in size, indicating the cleavage at $\operatorname{Arg}^{1689}$ of FVIII-L. Treatment of FXa to FVIII-L released a peptide with molecular weight of $65 \mathrm{kDa}$ and small peptides with molecular weight of $10 \mathrm{kDa}$, indicating that FXa cleaves at $\mathrm{Arg}^{1721}$ of FVIII-L in addition to $\operatorname{Arg}^{1689}$.

The activation process of FVIII is known to involve the limited proteolytic cleavage of FVIII protein by specific proteases such as thrombin and FXa (Harris et al., 1981) and further proteolysis by thrombin activated protein $\mathrm{C}$ (APC) inactivates FVIII as well as FV (Eaton et al., 1986; Fass, 1991). FXa activates FVIII by limited proteolysis at $\mathrm{Arg}^{336}$ of FVIII-H which is cleaved also by thrombin, APC, and FIXa. Proteolytic cleavage at both $\operatorname{Arg}^{336}$ and $\mathrm{Arg}^{373}$ of FVIII-H by thrombin or FXa may release a peptide comprising Ser ${ }^{337}-\mathrm{Arg}^{372}$ that will eventually inactivate FVIII (Eaton et al., 1986; O'Brien et al., 1992; Fay et al., 1993).

The increased cofactor activity by addition of sulfhydryl agent (2-mercaptoethanol) to FVIII subunits complex indicates the involvement of disulfide bond formation during the reassembly of FVIII which may increase the stability of subunit complex. The reassociation of thrombin treated FVIII-H and FVIII-L in the presence of calcium suggests that initial activation process of FVIII requires the limited proteolysis at $\mathrm{Arg}^{336}$ of FVIII H and $\mathrm{Arg}^{1689}$ of FVIII-L and calcium ion dependent heterodimer formation of these subunits.

Restoration of FVIII activity by FVIII-H subunits $(50 \mathrm{kDa}$ and $40 \mathrm{kDa}$ ) with either of FVIII-L $\mathrm{L}^{72}$ or FVIII-L $\mathrm{L}^{65}$ in the present study indicates that activation of FVIII involves the further proteolytic cleavage of FVIII peptides with thrombin or FXa and calcium-mediated heterotrimer formation.

Proteolytic cleavage of FVIII-L at Arg $^{1689}$ by thrombin or at $\operatorname{Arg}^{1721}$ by FXa did not influence on the FVIII cofactor activity but the lower association constant of FVIII-L ${ }^{72}$ with FVIII-H compared to that of FVIII-L ${ }^{65}$ with FVIII-H indicates that FVIII- $L^{72}$ has a higher binding affinity to FVIII-H than that of FXa cleaved FVIII-L ${ }^{65}$ has. This result is consistent with that reported by Donath et al. (1995).

Although the FVIII cofactor activities between FVIII-L ${ }^{65}$ bound form and FVIII-L $\mathrm{L}^{72}$ bound form were not much different, amino acid sequence (32 amino acids) between FVIII-L ${ }^{65}$ and FVIII-L ${ }^{72}$ has an important role in the association of subunit molecules to form heterodimer or heterotrimer.

\section{Acknowledgement}

This study is supported by Korean Ministry of Education through Basic Medical Research Fund (1996).

\section{References}

Andersson, L. O., Forsman, N., Huang, K., Larsen, K., Lundin, A., Pavlu, B., Sandberg, H., Sewerin, K. and Smart, J. (1986) Isolation and charac-terization of human factor VIII: Molecular forms in commercial factor VIII concentrate, cytoprecipitate and plasma. Proc. Natl. Acad. Sci. USA 83: 2979-2983

Bradford, M. M. (1976) A rapid and sensitive method for the quantitation of microgram quantities of protein utilizing the principle of protein-dye binding. Anal. Biochem. 72 : 248-254

Burnette, M. M. (1981) "Western blotting" electrophoreting transfer of protein from SDS PAGE to unmodified nitrocellulose and radioactive detection with antibody and radioiodinated protein A. Anal. Biochem. 112: 195-203

Carlebjok, G., Oswaldsson, U. and Rosens, A. (1987) A simple and accurate microplate assay for the determination of factor VIII activity. Thrombosis Res. 47: 5-14

Donath, M. S. H., Lenting, P. J., von Maurik, J. A. and Mertens, K. (1995) The role of cleavage of the light chain at position $\mathrm{Arg}^{1689}$ and $\mathrm{Arg}^{1721}$ in subunit interaction and activation of human blood coagulation factor VIII. J. Biol. Chem. 270: 3648-3655

Eaton, D., Rodriguez, H. and Vehar, G. A. (1986) Proteolytic processing of human factor VIII. Correlation of specific cleavage by thrombin, factor $\mathrm{Xa}$ and activated protein $\mathrm{C}$ with activation and inactivation of factor VIII coagulant activity. Biochemistry 25: 505512

Fass, D. N. (1991) Factor VIII structure and function. Ann. NY Acad. Sci 614: 76-88

Fay, P. J., Anderson, M. T., Chavin, S. I. and Marder, V. J. (1986) The size of human factor VIII heterodimers and the effect produced by thrombin. Biochim. Biophys. Acta 871: 268-276

Fay, P. J., Haidaris, P. J. and Huggins, C. F. (1993) Role of the COOH-terminal acidic region of A1 subunit in A2 subunit retention in human factor VIIla. J. Biol. Chem. 268: $17861-17866$

Fay, P. J. (1993) Factor VIII structure and function. Thromb. Haemost. 70: 63-67

Fulcher, C. A. and Zimmerman, T. S. (1982) Characterization of the human factor VIII procoagulant protein with a heterologous precipitating antibody. Proc. Natl. Acad. Sci. USA 79: 1648-1652

Harris, R. B., Johnson, A. J. and Hodgins, L. T. (1981) Partial purification of biologically active low molecular weight human antihemophilic factor free of von Willebrand factor. Biochim. Biophys. Acta 668, 471-480

Hoyer, L. W. and Trabold, N. C. (1981) Cleavage of the factor VIII procoagulant protein during activation. J. Lab. Clin. Med. 97: 50-64

Johnston, A. and Thorpe, R. (1987) Enzyme-linked immunosorbent assay (ELISA). In Immunochemistry in Practice, 2nd Ed., pp. 257-259, Blackwell, Oxford

Kaufman, R. J. (1992) Biological regulation of factor VIII activity. Ann. Rev. Med. 43: $325-339$

Kim, S. H. and Oh, S. H. (1994) Expression of human blood coagulation factor VIII in Chinese hamster ovary cells. Focus Genet. Sci. 2: 43-53

Laemmli, U. K. (1970) Cleavage of structural proteins during the assembly of the head of bacteriophage T4. Nature 227: 680-685 
Leyte, A., Mertens, K., Distel, B., Evers, R. F., Dekeyzer, N. M. J., Groenen-van Dooren, M. M. (1989) Inhibition of human coagulation factor VIII by monoclonal antibodies. Mapping of functional epitopes with the use of recombinant factor VIII fragments. Biochem. $J$. 263: 187-194

Lollar, P., Knutson, G. J. and Fass, D. N. (1985) Activation of porcine factor VIII:C by thrombin and factor Xa. Biochemistry 24: 8056-8064

Mahler, H. R. and Cordes, E. H. (1967) In Biological Chemistry, 2nd Ed., pp. 220-222, Harper and Row, London

Mertens, K., van Wijinggarden, A. and Bertina, R. M. (1985) The role of factor VIII in the activation of human blood coagulation factor $\mathrm{X}$ by activated factor IX. Thromb. Haemost. 54: $654-660$

Nordfang, O. and Ezban, M. (1988) Generation of active coagulation factor VIII from isolated subunits. J. Biol. Chem. 263: 1115-1118
O'Brien, D. P., Johnson, D., Byfield, P. and Tuddenham, E. C. D. (1992) Inactivation of factor VIII by factor IXa. Biochemistry 31: 2805-2815

Tool, J. J., Knopf, J. L., Wozney, J. M. Sultzman, L.A., Buecker, J. L. (1984) Molecular cloning of a cDNA encoding human anti-haemophilic factor. Nature 312: 342-347

Vehar, G. A. and Keyt, B., Eaton, D., Rodriguez, H., O'Brien, D. P., Rotblat, F., Oppermann, H., Keck, R., Lawn, R. M. and Capon, D. J. (1984) Structure of human factor VIII. Nature 312: 337-342 